\title{
Fabrication and oxidation resistance of mullite/yttrium silicate multilayer coatings on $\mathrm{C} / \mathrm{SiC}$ composites
}

\author{
Qingsong MA*, Lihui CAI \\ Science and Technology on Advanced Ceramic Fibers \& Composites Laboratory, National University of Defense \\ Technology, Changsha 410073, China
}

Received: May 16, 2017; Revised: July 18, 2017; Accepted: September 12, 2017

(C) The Author(s) 2017. This article is published with open access at Springerlink.com

\begin{abstract}
A tri-layer coating of mullite $/ \mathrm{Y}_{2} \mathrm{Si}_{2} \mathrm{O}_{7} /\left(70 \mathrm{wt} \% \mathrm{Y}_{2} \mathrm{Si}_{2} \mathrm{O}_{7}+30 \mathrm{wt} \% \mathrm{Y}_{2} \mathrm{SiO}_{5}\right)$ was prepared on carbon fiber reinforced silicon carbide $(\mathrm{C} / \mathrm{SiC})$ composite substrate through dip-coating route for the sake of improving oxidation resistance of $\mathrm{C} / \mathrm{SiC}$ composites. $\mathrm{An} \mathrm{Al}_{2} \mathrm{O}_{3}-\mathrm{SiO}_{2}$ sol with high solid content was selected as raw material for mullite, and a slurry of $\mathrm{Y}_{2} \mathrm{O}_{3}$ powder filled silicone resin was used to synthesize yttrium silicate. The microstructure, phase composition, and oxidation resistance of the coating were investigated. The as-fabricated coating shows high density and favorable bonding to $\mathrm{C} / \mathrm{SiC}$ substrate. After oxidation at 1400 and $1500{ }^{\circ} \mathrm{C}$ for 30 min under static air, the flexural strengths of coated $\mathrm{C} / \mathrm{SiC}$ composite were both increased by $\sim 30 \%$. The desirable thermal stability and the further densification are responsible for excellent oxidation resistance. With the additional help of compatible thermal expansion coefficients among substrate and sub-layers in coating, the coated composite retained $111.2 \%$ of original flexural strength after 12 times of thermal shock in air from $1400{ }^{\circ} \mathrm{C}$ to room temperature. The carbothermal reaction at $1600{ }^{\circ} \mathrm{C}$ between free carbon in $\mathrm{C} / \mathrm{SiC}$ substrate and rich $\mathrm{SiO}_{2}$ in mullite resulted in severe frothing and desquamation of coating and obvious degradation in oxidation resistance.
\end{abstract}

Keywords: oxidation resistance; thermal shock resistance; coatings; mullite; yttrium silicate; $\mathrm{C} / \mathrm{SiC}$ composites

\section{Introduction}

Carbon fiber reinforced silicon carbide $(\mathrm{C} / \mathrm{SiC})$ composites have been well developed as a desirable candidate for thermo structural and tribological applications for about thirty years [1-3]. For applications in air, anti-oxidation should be paid much attention due to the inevitable formation of pores and microcracks. The pores and microcracks resulting from the intrinsic characteristics of fabrication technologies

*Corresponding author

E-mail: nudtmqs1975@163.com and the mismatch of thermal expansion coefficient between fiber and matrix $[4,5]$ make it easy for oxygen to diffuse into $\mathrm{C} / \mathrm{SiC}$ composites and then oxidize carbon fibers and free carbon in matrix [6,7]. So far, several methods have been explored to protect $\mathrm{C} / \mathrm{SiC}$ composites from oxidation in which external coating is demonstrated to be the most effective one [8,9].

Yttrium silicate $\left(\mathrm{Y}_{2} \mathrm{Si}_{2} \mathrm{O}_{7}\right.$ and $\mathrm{Y}_{2} \mathrm{SiO}_{5}$ phases $)$, which possesses advantages such as high melt point, low oxygen permeability, favorable thermal and chemical stability, low modulus, and matchable thermal expansion coefficient with $\mathrm{SiC}$, has been studied extensively as external anti-oxidation coating for $\mathrm{C} / \mathrm{C}$ and $\mathrm{C} / \mathrm{SiC}$ composites [10-13]. Some measures 
including plasma spray [10], electrophoretic deposition [11], sol-gel [12], slurry brushing, and sintering [13] have been employed to fabricate yttrium silicate coating. Recently, a new route to synthesize yttrium silicate from the pyrolysis of $\mathrm{Y}_{2} \mathrm{O}_{3}$ powder filled silicone resin has been reported $[14,15]$. This route is a promising method because of good adhesive and covering ability of silicone resin, low process temperature, and relatively low cost $[16,17]$. Dense $\mathrm{Y}_{2} \mathrm{Si}_{2} \mathrm{O}_{7}$ coating was fabricated on $\mathrm{SiC}$ foam by pyrolysis in air of silicone resin containing $\mathrm{Y}_{2} \mathrm{O}_{3}$ powders [14], but the oxidation protection for $\mathrm{C} / \mathrm{SiC}$ composites was not investigated. The $\mathrm{Y}_{2} \mathrm{Si}_{2} \mathrm{O}_{7}$ coating in the study of Liu et al. [15] displayed good oxidation protection for $\mathrm{C} / \mathrm{SiC}$ composites at $1400{ }^{\circ} \mathrm{C}$. However, the residual free carbon and pores in coating due to the pyrolysis of silicone resin in inert atmosphere would be detrimental to oxidation resistance at higher temperature. In our previous work [18], $\mathrm{Y}_{2} \mathrm{Si}_{2} \mathrm{O}_{7}$ coating was fabricated directly on $\mathrm{C} / \mathrm{SiC}$ composite substrate by dip-coating from $\mathrm{Y}_{2} \mathrm{O}_{3}$ powder filled silicone resin and provided excellent oxidation resistance at $1400-1600{ }^{\circ} \mathrm{C}$. At the same time, it was observed that $\mathrm{C} / \mathrm{SiC}$ composites were damaged to a certain extent by the conversion of silicone resin to $\mathrm{SiO}_{2}$ at $800{ }^{\circ} \mathrm{C}$ in air.

In fact, inner $\mathrm{SiC}$ coating was usually prepared on $\mathrm{C} / \mathrm{C}$ or $\mathrm{C} / \mathrm{SiC}$ composite substrate before yttrium silicate coating [10] in order to enhance bonding strength and prevent carbon diffusion. Nevertheless, oxygen would diffuse through cracks and pores in yttrium silicate coating and oxidize $\mathrm{SiC}$ coating during long-time oxidation, resulting in desquamation or split of external coating [19]. To avoid the above problem, inner $\mathrm{SiC}$ coating was replaced by mullite coating derived from $\mathrm{Al}_{2} \mathrm{O}_{3}-\mathrm{SiO}_{2}$ sol [20], and mullite $/ \mathrm{Y}_{2} \mathrm{Si}_{2} \mathrm{O}_{7}$ double-layer coating with desirable anti-oxidation performance and thermal shock resistance has been obtained [21]. However, some pores and microcracks were still formed due to the intrinsic characteristics of sol-gel and slurry method. Although a top layer of borosilicate glass could seal theses pores and microcracks and improve oxidation resistance [22], its low melt point and high reactivity in water-vapor are disadvantageous to the thermal stability of coating.

It has been found that the yttrium silicate coating with gradient composition showed higher density and better oxidation resistance than single-layer yttrium silicate coating [10]. The layer of $70 \mathrm{wt} \% \mathrm{Y}_{2} \mathrm{Si}_{2} \mathrm{O}_{7}$ $+30 \mathrm{wt} \% \mathrm{Y}_{2} \mathrm{SiO}_{5}$ not only had a thermal expansion coefficient close to those of $\mathrm{C} / \mathrm{SiC}$ and $\mathrm{Y}_{2} \mathrm{Si}_{2} \mathrm{O}_{7}$ but also showed desirable oxidation resistance $[15,19]$. Once the content of $\mathrm{Y}_{2} \mathrm{SiO}_{5}$ was more than $30 \mathrm{wt} \%$, the thermal mismatch between $\mathrm{Y}_{2} \mathrm{Si}_{2} \mathrm{O}_{7}$ and $70 \mathrm{wt} \% \mathrm{Y}_{2} \mathrm{Si}_{2} \mathrm{O}_{7}$ $+30 \mathrm{wt} \% \mathrm{Y}_{2} \mathrm{SiO}_{5}$ would be enlarged, very likely leading to delamination and desquamation. So, in order to improve oxidation resistance of mullite $/ \mathrm{Y}_{2} \mathrm{Si}_{2} \mathrm{O}_{7}$ double-layer coating, a top layer of $70 \mathrm{wt} \% \mathrm{Y}_{2} \mathrm{Si}_{2} \mathrm{O}_{7}$ $+30 \mathrm{wt} \% \mathrm{Y}_{2} \mathrm{SiO}_{5}$ was introduced in this paper. The fabrication and oxidation resistance of mullite/ $\mathrm{Y}_{2} \mathrm{Si}_{2} \mathrm{O}_{7} /\left(70 \mathrm{wt} \% \mathrm{Y}_{2} \mathrm{Si}_{2} \mathrm{O}_{7}+30 \mathrm{wt} \% \mathrm{Y}_{2} \mathrm{SiO}_{5}\right) \quad$ tri-layer coating were investigated.

\section{Experimental}

\section{1 Raw materials}

The substrate was $\mathrm{C} / \mathrm{SiC}$ composites with an apparent density of $1.92 \mathrm{~g} / \mathrm{cm}^{3}$ and an open porosity of $9.8 \%$. The $\mathrm{C} / \mathrm{SiC}$ substrates with a size of $70 \mathrm{~mm} \times 5 \mathrm{~mm} \times 4 \mathrm{~mm}$ were fabricated by polycarbosilane infiltration and pyrolysis in our own lab. The $\mathrm{Al}_{2} \mathrm{O}_{3}-\mathrm{SiO}_{2}$ diphasic sol with a solid content of $22 \%$ and an $\mathrm{Al}_{2} \mathrm{O}_{3} / \mathrm{SiO}_{2}$ mass ratio of 1:2 was selected as raw material for mullite coating. Commercially available flake silicone resin with a trademark of DC249 (Dow Corning Co. Ltd., USA) and $\mathrm{Y}_{2} \mathrm{O}_{3}$ powders (Sinopharm Chemical Reagent Co. Ltd., Shanghai, China) with a diameter of 2-3 $\mu \mathrm{m}$ and a purity of $99.99 \%$ were used to synthesize yttrium silicate. According to the chemical compositions of $\mathrm{Y}_{2} \mathrm{Si}_{2} \mathrm{O}_{7}$ and $70 \mathrm{wt} \% \mathrm{Y}_{2} \mathrm{Si}_{2} \mathrm{O}_{7}$ $+30 \mathrm{wt} \% \mathrm{Y}_{2} \mathrm{SiO}_{5}$ and the ceramic yield $(\sim 63 \%)$ of silicone resin in air, the mass ratios of $\mathrm{Y}_{2} \mathrm{O}_{3}$ to silicone resin were set to $54.2: 45.8$ and 58.8:41.2, respectively. Silicone resin was dissolved in anhydrous ethanol, to which $\mathrm{Y}_{2} \mathrm{O}_{3}$ powders were added. After stirred for $4 \mathrm{~h}$, the slurries for yttrium silicate coatings were obtained.

\section{2 Fabrication of coatings}

$\mathrm{C} / \mathrm{SiC}$ composite substrate was dipped in $\mathrm{Al}_{2} \mathrm{O}_{3}-\mathrm{SiO}_{2}$ sol for $5 \mathrm{~min}$, then pulled out with a constant speed and dried at $100{ }^{\circ} \mathrm{C}$ for $1 \mathrm{~h}$. After the dipping-drying cycle was repeated 5 times, $\mathrm{C} / \mathrm{SiC}$ composite substrate was heated at $1400{ }^{\circ} \mathrm{C}$ for $1 \mathrm{~h}$ under flowing high purity argon. The mullite coating was obtained by repeating 4 times of the process of dipping-drying (5 times) and heat treatment.

The preparation of $\mathrm{Y}_{2} \mathrm{Si}_{2} \mathrm{O}_{7}$ coating included three steps, namely, dip-coating, pre-pyrolysis, and heat treatment. In the first step, mullite-coated $\mathrm{C} / \mathrm{SiC}$ 
composite substrate was dipped in slurry for $5 \mathrm{~min}$, then drawn out with a constant speed and dried at $80{ }^{\circ} \mathrm{C}$ for $1 \mathrm{~h}$. After repeating 4 times of dip-coating process, $\mathrm{C} / \mathrm{SiC}$ composite substrate was heated at $250{ }^{\circ} \mathrm{C}$ for $2 \mathrm{~h}$ to cure silicone resin, followed by pre-pyrolysis at $800{ }^{\circ} \mathrm{C}$ for $1 \mathrm{~h}$ in air to convert silicone resin into $\mathrm{SiO}_{2}$. The process consisting of dip-coating (4 times) and pre-pyrolysis was repeated for 3 times. Finally, the mullite $/ \mathrm{Y}_{2} \mathrm{Si}_{2} \mathrm{O}_{7}$ coated $\mathrm{C} / \mathrm{SiC}$ composites were obtained after heat treatment at $1400{ }^{\circ} \mathrm{C}$ for $1 \mathrm{~h}$ under flowing high purity argon. The fabrication of $70 \mathrm{wt} \% \mathrm{Y}_{2} \mathrm{Si}_{2} \mathrm{O}_{7}+30 \mathrm{wt} \% \mathrm{Y}_{2} \mathrm{SiO}_{5}$ coating was almost the same as $\mathrm{Y}_{2} \mathrm{Si}_{2} \mathrm{O}_{7}$ coating, except the slurry.

\section{3 Characterization of coatings}

Static oxidation was performed in a muffle which was preset at 1400,1500 , and $1600{ }^{\circ} \mathrm{C}$. The as-received coated $\mathrm{C} / \mathrm{SiC}$ composites were placed on $\mathrm{Al}_{2} \mathrm{O}_{3}$ bracket and oxidized for $30 \mathrm{~min}$. Thermal shock in air from $1400{ }^{\circ} \mathrm{C}$ to room temperature was carried out 12 times. The muffle was heated to $1400{ }^{\circ} \mathrm{C}$ in advance. The as-received coated $\mathrm{C} / \mathrm{SiC}$ composites were put into muffle and soaked at $1400{ }^{\circ} \mathrm{C}$ for $10 \mathrm{~min}$, followed by rapid removal to ambient atmosphere. After the temperature lowered to room temperature, the $\mathrm{C} / \mathrm{SiC}$ composites were put into muffle again.

The weight loss and the flexural strength retention after oxidation and thermal shock were recorded to characterize the oxidation and thermal shock resistance of tri-layer coating. The flexural strength was measured by a three-point bending method with a cross-head speed of $0.5 \mathrm{~mm} / \mathrm{min}$ and a span/height ratio of 15 . Scanning electron microscope (SEM), energy dispersive spectroscopy (EDS) (Quanta-200 EDAX), and X-ray diffraction (XRD) were employed to observe the changes of microstructure, element, and phase of coating after oxidation and thermal shock, respectively. XRD measurements were carried out on a diffractometer (D/max-2400, Rigaku) with $\mathrm{Cu} \mathrm{K \alpha}$ radiation. Data were digitally recorded during a continuous scan in the range of angle $(2 \theta)$ from $10^{\circ}$ to $80^{\circ}$ with a scanning rate of $4\left(^{\circ}\right) / \mathrm{min}$.

\section{Results and discussion}

\section{1 Fabrication and microstructure of tri-layer coating}

The synthesis of mullite [20] and $\mathrm{Y}_{2} \mathrm{Si}_{2} \mathrm{O}_{7}[18]$ has been studied in our previous studies. For the synthesis of $\mathrm{Y}_{2} \mathrm{SiO}_{5}$ phase, the relative mass ratio of $\mathrm{Y}_{2} \mathrm{O}_{3} /$ silicone resin in slurry was $70.3 / 29.7$. The slurry was dried, cured, and pre-pyrolyzed in air, followed by heating in high purity $\mathrm{Ar}$ at $1200-1400{ }^{\circ} \mathrm{C}$. In the same way, there are only $\mathrm{Y}_{2} \mathrm{O}_{3}$ diffraction peaks after pre-pyrolysis at $800{ }^{\circ} \mathrm{C}$ in air, as shown in Ref. [18]. Figure 1 shows XRD patterns of the production after heat treatment.

The emergence of obvious diffraction peaks of $\mathrm{Y}_{2} \mathrm{SiO}_{5}$ phase is observed at $1200{ }^{\circ} \mathrm{C}$, indicating that the reaction between $\mathrm{Y}_{2} \mathrm{O}_{3}$ and $\mathrm{SiO}_{2}$ takes place at this temperature. The intensity of $\mathrm{Y}_{2} \mathrm{SiO}_{5}$ diffraction peaks is gradually enhanced by increasing temperature, accompanied by the gradual decline of $\mathrm{Y}_{2} \mathrm{O}_{3}$ peaks. At $1400{ }^{\circ} \mathrm{C}$, most of peaks can be assigned to $\mathrm{Y}_{2} \mathrm{SiO}_{5}$ phase, implying that the reaction between $\mathrm{Y}_{2} \mathrm{O}_{3}$ and $\mathrm{SiO}_{2}$ is basically finished. The completion of $\mathrm{Y}_{2} \mathrm{Si}_{2} \mathrm{O}_{7}$ synthesis at $1400{ }^{\circ} \mathrm{C}$ has also been confirmed in previous work $[18,21]$. Moreover, the formation of $\mathrm{Y}_{2} \mathrm{SiO}_{5}$ phase was demonstrated to be prior to $\mathrm{Y}_{2} \mathrm{Si}_{2} \mathrm{O}_{7}$ phase [14]. However, diffraction peaks of $\mathrm{Y}_{2} \mathrm{O}_{3}$ can be found in the spectrum of $1400{ }^{\circ} \mathrm{C}$. This may be explained by two reasons. One is a slight deviation of $\mathrm{Y}_{2} \mathrm{O}_{3} / \mathrm{SiO}_{2}$ mass ratio from the stoichiometric composition of $\mathrm{Y}_{2} \mathrm{SiO}_{5}$ due to the fluctuation of ceramic yield of silicone resin in air. The other is that mixture uniformity is not good enough.

Figure 2 shows the XRD spectrum of $70 \mathrm{wt} \% \mathrm{Y}_{2} \mathrm{Si}_{2} \mathrm{O}_{7}$ $+30 \mathrm{wt} \% \mathrm{Y}_{2} \mathrm{SiO}_{5}$ sub-layer in as-received coating. It is evident that $\mathrm{Y}_{2} \mathrm{Si}_{2} \mathrm{O}_{7}$ and $\mathrm{Y}_{2} \mathrm{SiO}_{5}$ phases are well developed after heat treatment at $1400{ }^{\circ} \mathrm{C}$. At the same time, it is noted that the diffraction peaks of $\mathrm{Y}_{2} \mathrm{SiO}_{5}$ phase are in the majority, which is not corresponding to the molar fraction $(34.1 \%)$ of $\mathrm{Y}_{2} \mathrm{SiO}_{5}$ phase. On one hand, prior formation of $\mathrm{Y}_{2} \mathrm{SiO}_{5}$ has been affirmed [14],

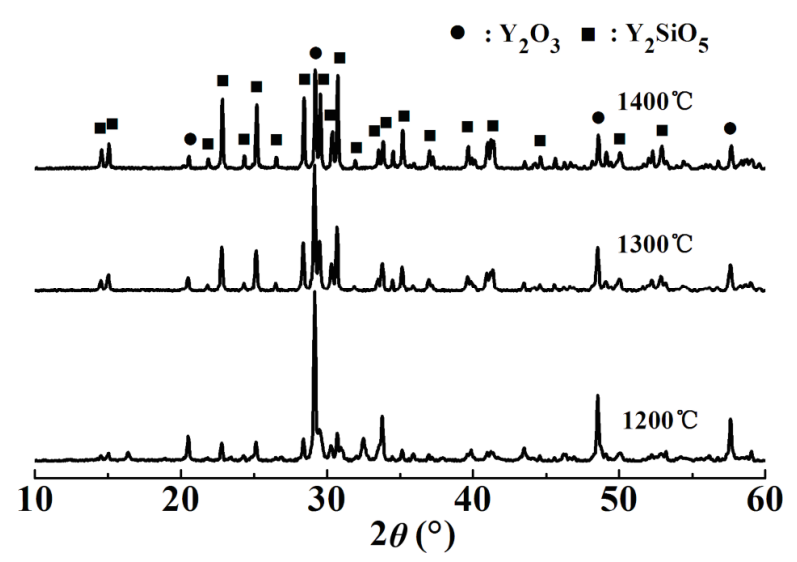

Fig. 1 XRD patterns of $\mathrm{Y}_{2} \mathrm{O}_{3}$ powder filled silicone resin after heat treatment at various temperatures. 
and higher temperature $\left(>1400{ }^{\circ} \mathrm{C}\right)$ is necessary for the conversion from $\mathrm{Y}_{2} \mathrm{SiO}_{5}$ to $\mathrm{Y}_{2} \mathrm{Si}_{2} \mathrm{O}_{7}$ because $\mathrm{SiO}_{2}$ in $70 \mathrm{wt} \% \mathrm{Y}_{2} \mathrm{Si}_{2} \mathrm{O}_{7}+30 \mathrm{wt} \% \mathrm{Y}_{2} \mathrm{SiO}_{5}$ is not enough as compared with that in $\mathrm{Y}_{2} \mathrm{Si}_{2} \mathrm{O}_{7}$. On the other hand, the positions of $\mathrm{Y}_{2} \mathrm{Si}_{2} \mathrm{O}_{7}$ and $\mathrm{Y}_{2} \mathrm{SiO}_{5}$ peaks are very close to each other, even the same [15]. Accordingly, the $\mathrm{Y}_{2} \mathrm{Si}_{2} \mathrm{O}_{7}$ peaks are likely to be enshrouded by those of $\mathrm{Y}_{2} \mathrm{SiO}_{5}$ phase.

SEM appearance and EDS of as-received tri-layer coating are displayed in Fig. 3. It is clear from Fig. 3(a) that there are several microcracks besides some pores in the top layer of $70 \mathrm{wt} \% \mathrm{Y}_{2} \mathrm{Si}_{2} \mathrm{O}_{7}+30 \mathrm{wt} \% \mathrm{Y}_{2} \mathrm{SiO}_{5}$. The microcracks were not obvious in mullite $/ \mathrm{Y}_{2} \mathrm{Si}_{2} \mathrm{O}_{7}$ coating [21]. Thus, the microcracks result from the thermal expansion mismatch between $\mathrm{Y}_{2} \mathrm{Si}_{2} \mathrm{O}_{7}$ and $70 \mathrm{wt} \% \mathrm{Y}_{2} \mathrm{Si}_{2} \mathrm{O}_{7}+30 \mathrm{wt} \% \mathrm{Y}_{2} \mathrm{SiO}_{5}$ since the thermal expansion coefficient of $\mathrm{Y}_{2} \mathrm{SiO}_{5}$ is much higher than that of $\mathrm{Y}_{2} \mathrm{Si}_{2} \mathrm{O}_{7}[15,23,24]$. Moreover, Fig. 2 indicates that the content of $\mathrm{Y}_{2} \mathrm{SiO}_{5}$ in top layer is more than 30wt\%. As shown in Fig. 3(b), tri-layer coating shows tight bonding to $\mathrm{C} / \mathrm{SiC}$ substrate and indistinct interfaces among sub-layers. The thickness of tri-layer coating is estimated to be $200-250 \mu \mathrm{m}$ from cross-section. The tight bonding can be ascribed to the viscous flow effect of rich $\mathrm{SiO}_{2}$ in mullite [20] and the thermal expansion matching between substrate and mullite. The incompletely dense mullite coating [20], $\mathrm{Y}_{2} \mathrm{Si}_{2} \mathrm{O}_{7}$ coating [18,21], and the viscous flow effect of amorphous $\mathrm{SiO}_{2}$ derived from silicone resin are responsible for the indistinct interfaces. In addition, the oxidation damage to $\mathrm{C} / \mathrm{SiC}$ substrate from pyrolysis of silicone resin in air [18] is not observed in this study because of the protection of mullite coating, which has been confirmed in previous work [21]. Theoretical element compositions of the top layer of $70 \mathrm{wt} \% \mathrm{Y}_{2} \mathrm{Si}_{2} \mathrm{O}_{7}+30 \mathrm{wt} \% \mathrm{Y}_{2} \mathrm{SiO}_{5}$ are 63.32 at $\% \mathrm{O}, 16.63$

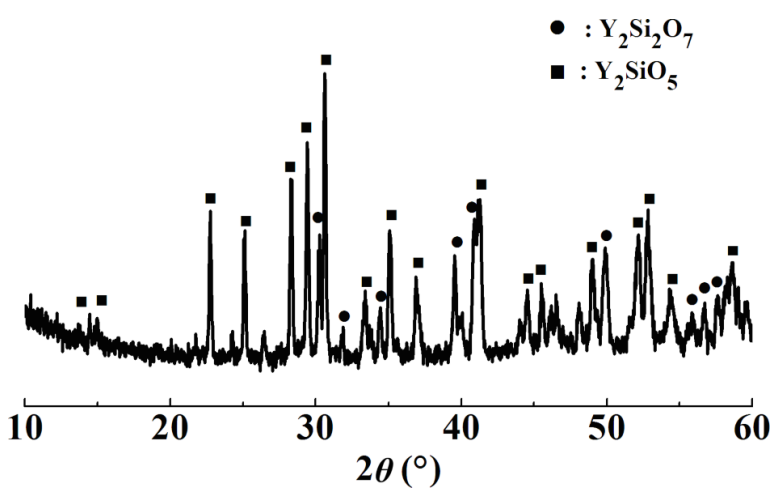

Fig. 2 XRD pattern of $70 w t \% \mathrm{Y}_{2} \mathrm{Si}_{2} \mathrm{O}_{7}+30 \mathrm{wt} \% \mathrm{Y}_{2} \mathrm{SiO}_{5}$ sub-layer in as-received coating. at $\% \mathrm{Si}$, and $20.05 \mathrm{at} \% \mathrm{Y}$, and the EDS result of selected point $\mathrm{A}$ in Fig. 3(a) is shown in Fig. 3(c). In consideration of the semi-quantitative characteristic of EDS analysis and the incompletely uniform distribution of $\mathrm{Y}_{2} \mathrm{O}_{3}$ powders in silicone resin, the two results are well coincident.

\section{2 Oxidation resistance of tri-layer coating}

After oxidation at 1400,1500 , and $1600{ }^{\circ} \mathrm{C}$ for $30 \mathrm{~min}$, the weight change and flexural strength retention of coated $\mathrm{C} / \mathrm{SiC}$ composites are showed in Table 1 . It is noted that the coated composites exhibit tiny weight gain after oxidation at 1400 and $1500{ }^{\circ} \mathrm{C}$. Theoretically speaking, the weight of tri-layer coating should not be increased during oxidation. It is very likely that the tiny weight gain is due to the slight cohesion of $\mathrm{Al}_{2} \mathrm{O}_{3}$ bracket to coating. In the work of Huang et al. [25], it
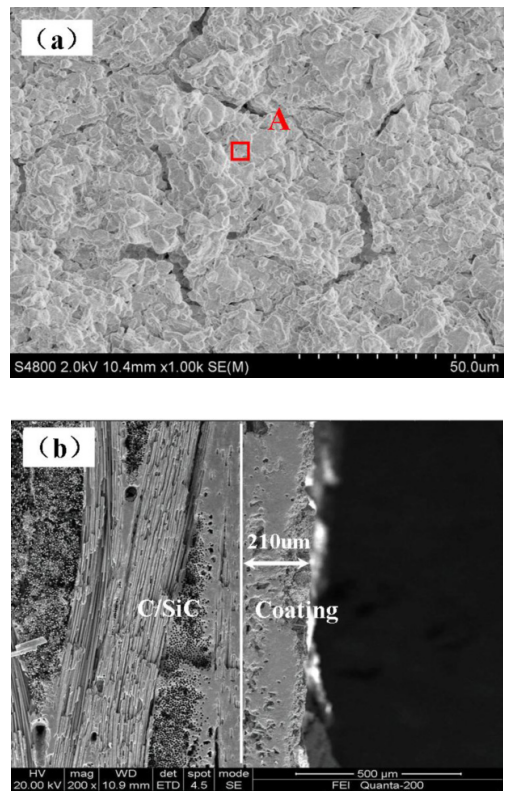

(c)

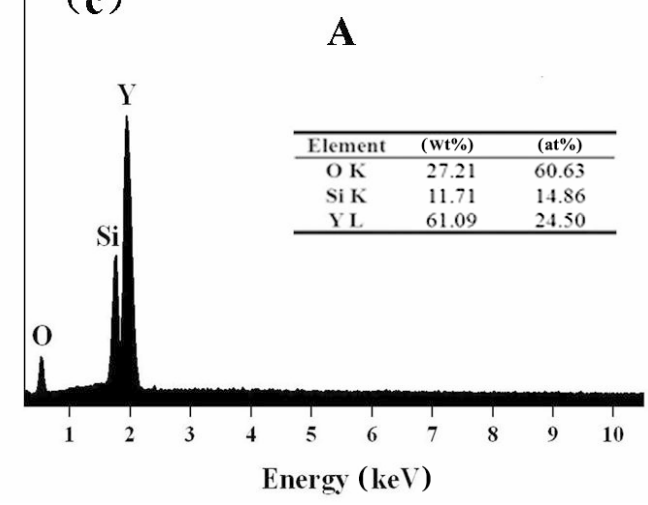

Fig. 3 SEM photos of (a) surface and (b) cross-section, and (c) EDS result of as-received coating. 
was confirmed that the reaction between yttrium silicate and $\mathrm{Al}_{2} \mathrm{O}_{3}$ bracket took place at $1500{ }^{\circ} \mathrm{C}$. Our previous study [18] has validated this phenomenon. As for the weight loss of $18.66 \%$ at $1600{ }^{\circ} \mathrm{C}$, it is not the fact and will be explained later. The flexural strength retention suggests that the tri-layer coating provides desirable oxidation protection for $\mathrm{C} / \mathrm{SiC}$ composites.

Figure 4 presents load-displacement curves of coated $\mathrm{C} / \mathrm{SiC}$ composites before and after oxidation. As shown, all the coated composites illustrate non-catastrophic fracture behavior with a maximum displacement of $\sim 2.0 \mathrm{~mm}$ at invalidation point. The fracture surfaces of coated composites, which are similar to those of mullite $/ \mathrm{Y}_{2} \mathrm{Si}_{2} \mathrm{O}_{7}$ coating [21] and not presented in this paper, show extensive fiber pull-out and long pull-out length before and after oxidation. In combination with the data in Table 1, it is indicated that tri-layer coating is a desirable candidate of anti-oxidation for $\mathrm{C} / \mathrm{SiC}$ composites.

To elucidate the anti-oxidation mechanism of tri-layer coating, XRD patterns and surface morphology after oxidation were recorded and presented in Figs. 5 and 6, respectively. In Fig. 5, the spectrum at $1400{ }^{\circ} \mathrm{C}$ is almost the same as that of as-received coating except the two faint peaks at $\sim 27.5^{\circ}$ and $\sim 28.8^{\circ}$. The two faint peaks are assigned to $\mathrm{Y}_{2} \mathrm{Si}_{2} \mathrm{O}_{7}$ phase. After oxidation at

Table 1 Weight change and flexural strength of coated $\mathrm{C} / \mathrm{SiC}$ composites after oxidation

\begin{tabular}{ccccc}
\hline $\begin{array}{c}\text { Oxidation } \\
\text { temperature }\end{array}$ & $\begin{array}{c}\text { Room } \\
\text { temperature }\end{array}$ & $1400{ }^{\circ} \mathrm{C}$ & $1500{ }^{\circ} \mathrm{C}$ & $1600{ }^{\circ} \mathrm{C}$ \\
\hline $\begin{array}{c}\text { Weight change } \\
\text { Flexural } \\
\text { strength (MPa) } \\
\text { Flexural } \\
\text { strength } \\
\text { retention }\end{array}$ & - & $0.58 \%$ & $0.93 \%$ & $-18.66 \%$ \\
\hline
\end{tabular}

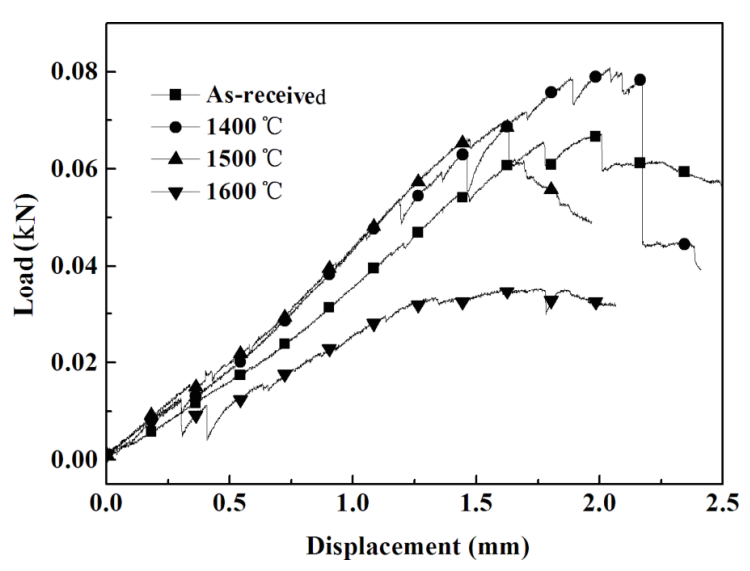

Fig. 4 Load-displacement curves of coated $\mathrm{C} / \mathrm{SiC}$ composites before and after oxidation.

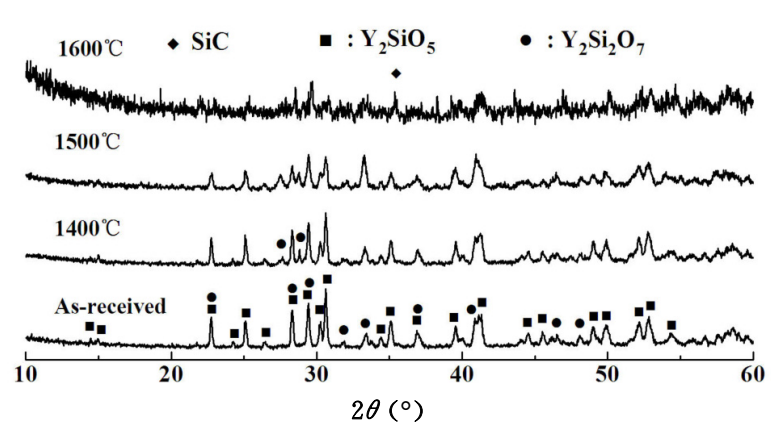

Fig. 5 XRD patterns of tri-layer coating before and after oxidation.

$1500{ }^{\circ} \mathrm{C}$, the peaks at $\sim 27.5^{\circ}$ and $\sim 33.3^{\circ}$, which belong to $\mathrm{Y}_{2} \mathrm{Si}_{2} \mathrm{O}_{7}$ phase, are obviously strengthened. At the same time, the peaks at $\sim 25^{\circ}, \sim 31^{\circ}$, and $\sim 35^{\circ}$, which are assigned to $\mathrm{Y}_{2} \mathrm{SiO}_{5}$ phase, are weakened. As mentioned above, $\mathrm{Y}_{2} \mathrm{SiO}_{5}$ phase is predominant in the top layer of as-received coating (Fig. 2) although the nominal composition is $70 \mathrm{wt} \% \mathrm{Y}_{2} \mathrm{Si}_{2} \mathrm{O}_{7}+30 \mathrm{wt} \% \mathrm{Y}_{2} \mathrm{SiO}_{5}$. This implies that the synthesis of $70 \mathrm{wt} \% \mathrm{Y}_{2} \mathrm{Si}_{2} \mathrm{O}_{7}$ was not completed at $1400{ }^{\circ} \mathrm{C}$ for $1 \mathrm{~h}$. XRD results indicate that the transformation from $\mathrm{Y}_{2} \mathrm{SiO}_{5}$ to $\mathrm{Y}_{2} \mathrm{Si}_{2} \mathrm{O}_{7}$ can be promoted by prolonging heat treatment time or increasing heat treatment temperature. So, the fabrication of coating should be performed at $1400{ }^{\circ} \mathrm{C}$ for a long time or at higher temperature if the complete synthesis of $\mathrm{Y}_{2} \mathrm{Si}_{2} \mathrm{O}_{7}$ phase is expected.

As shown in Fig. 6(a), the microcracks and pores in Fig. 3(a) disappear and a dense surface is observed after oxidation at $1400{ }^{\circ} \mathrm{C}$ for $30 \mathrm{~min}$. At $1500{ }^{\circ} \mathrm{C}$, further densification of coating surface is discovered. Owing to the transformation from $\mathrm{Y}_{2} \mathrm{SiO}_{5}$ to $\mathrm{Y}_{2} \mathrm{Si}_{2} \mathrm{O}_{7}$ during oxidation, volume expansion takes place since the density of $\mathrm{Y}_{2} \mathrm{SiO}_{5}\left(4.53 \mathrm{~g} / \mathrm{cm}^{3}\right)$ is higher than that of $\mathrm{Y}_{2} \mathrm{Si}_{2} \mathrm{O}_{7}\left(4.15 \mathrm{~g} / \mathrm{cm}^{3}\right)$ [14], and the thermal expansion mismatch between the top layer and the interlayer of $\mathrm{Y}_{2} \mathrm{Si}_{2} \mathrm{O}_{7}$ is reduced because of the lower thermal expansion coefficient of $\mathrm{Y}_{2} \mathrm{Si}_{2} \mathrm{O}_{7}$ as compared with $\mathrm{Y}_{2} \mathrm{SiO}_{5}[15,23,24]$. As a result, the microcracks and pores are healed. In addition, solid-state sintering of yttrium silicate is also responsible for the further densification of coating [18]. Profiting from the densification of coating, the diffusion of oxygen into composites is effectively impeded, and the resistance to crack creation and propagation is enhanced. Therefore, the flexural strengths of coated $\mathrm{C} / \mathrm{SiC}$ composites are increased by $\sim 30 \%$ after oxidation at 1400 and $1500{ }^{\circ} \mathrm{C}$.

By comparing Fig. 2(b) in Ref. [21] with Fig. 3(b) in this paper, it is found that the pores in the cross section 


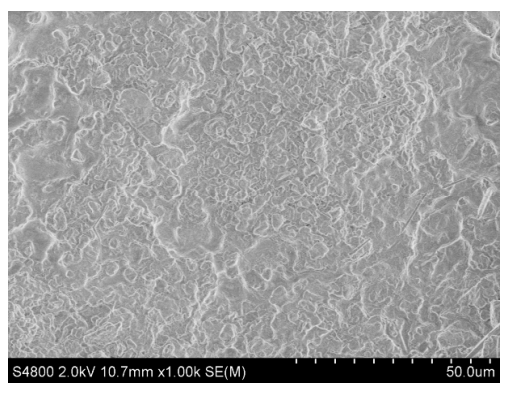

(a) $1400{ }^{\circ} \mathrm{C}$ oxidation

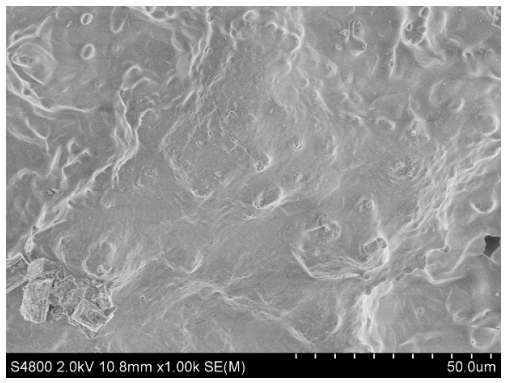

(b) $1500{ }^{\circ} \mathrm{C}$ oxidation

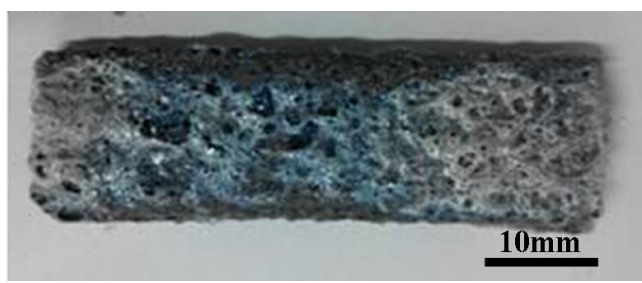

(c) $1600{ }^{\circ} \mathrm{C}$ oxidation

Fig. 6 SEM photos of tri-layer coating after oxidation.

of double-layer coating were not observed in tri-layer coating. This suggests that the tri-layer coating has higher density and validates the results of Huang et al. [10]. On one hand, the pores in interlayer could be filled by the slurry during the dip-coating of top layer. On the other hand, the top layer exerted compressive stress on the interlayer due to the higher thermal expansion coefficient of top layer. The compressive stress was helpful to the densification of interlayer. As mentioned above, the cracks in the top layer resulting from tensile stress would be healed during high temperature oxidation. By comparing Fig. 6(b) and Fig. 6(c) in Ref. [21] with Fig. 6(a) and Fig. 6(b) in this paper, it is obvious that the tri-layer coating exhibits more compacted surface after oxidation at 1400 and $1500{ }^{\circ} \mathrm{C}$. As a result, the flexural strength retention ratios of the composites with tri-layer coating $\left(127.8 \%\right.$ at $1400{ }^{\circ} \mathrm{C}$ and $130.1 \%$ at $1500{ }^{\circ} \mathrm{C}$ ) are much higher than those of the composites with double-layer coating $(91.9 \%$ at $1400{ }^{\circ} \mathrm{C}$ and $102.4 \%$ at $1500{ }^{\circ} \mathrm{C}$ ).

However, severe frothing and desquamation of

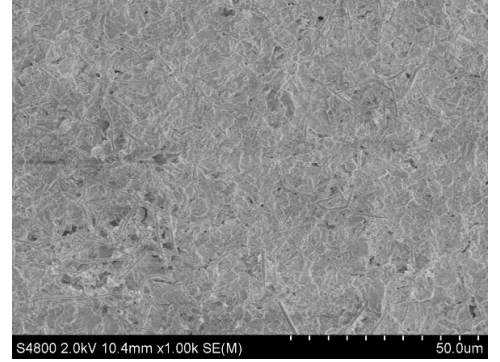

Fig. 7 SEM photo of tri-layer coating after thermal shock.

coating is observed after oxidation at $1600{ }^{\circ} \mathrm{C}$ for 30 min, as shown in Fig. 6(c). This phenomenon can be attributed to the carbothermal reaction between rich $\mathrm{SiO}_{2}$ in mullite sub-layer and free carbon in composite substrate [20]. Accordingly, the disappearance of some diffraction peaks of yttrium silicate and the emergence of $\mathrm{SiC}$ diffraction peak are observed in XRD pattern (Fig. 5). Porous $\mathrm{C} / \mathrm{SiC}$ composite substrate is inevitably oxidized without the protection of tri-layer coating. Coating desquamation and subsequent oxidation of substrate result in the obvious weight loss of $18.66 \%$ and the remarkable degradation in flexural strength.

\section{3 Thermal shock resistance of tri-layer coating}

After 12 times of thermal shock from $1400{ }^{\circ} \mathrm{C}$ to room temperature in air, the coated $\mathrm{C} / \mathrm{SiC}$ composites show a tiny weight gain of $0.36 \%$ and a flexural strength retention ratio of $111.2 \%$. The load-displacement curve of coated $\mathrm{C} / \mathrm{SiC}$ composite after thermal shock, which is very similar to that of $1400{ }^{\circ} \mathrm{C}$ in Fig. 4 , illustrates typical non-catastrophic fracture behavior. Figure 7 shows SEM photo of coating surface after thermal shock. The XRD pattern of coating after thermal shock is not presented here since it is very similar to that of $1400{ }^{\circ} \mathrm{C}$ in Fig. 5.

During thermal shock test, the coated $\mathrm{C} / \mathrm{SiC}$ composites endured not only sudden change of temperature but also oxidation at $1400{ }^{\circ} \mathrm{C}$ for $120 \mathrm{~min}$. As mentioned above, the oxidation can promote the transformation of $\mathrm{Y}_{2} \mathrm{SiO}_{5}$ to $\mathrm{Y}_{2} \mathrm{Si}_{2} \mathrm{O}_{7}$, leading to volume expansion and reduction in thermal expansion coefficient. So, the large-size cracks in as-received coating (Fig. 3(a)) are eliminated after thermal shock. With the increase of $\mathrm{Y}_{2} \mathrm{Si}_{2} \mathrm{O}_{7}$ phase content, the difference in thermal expansion coefficient between the top layer and the interlayer of $\mathrm{Y}_{2} \mathrm{Si}_{2} \mathrm{O}_{7}$ decreases. Thanks to the matched thermal expansion coefficients among substrate, mullite, and yttrium silicate, no macroscopic cracks and coating desquamation are 
found after thermal shock. However, some micropores and microcracks are still observed in Fig. 7. As compared with Fig. 6(a), the densification is inferior. It is deemed that the micropores and microcracks are created by the local thermal stress derived from the repeating thermal shock and the incompletely uniform distribution of coating composition. Thus, the flexural strength retention ratio is lower than those after static oxidation at 1400 and $1500{ }^{\circ} \mathrm{C}$.

\section{Conclusions}

A tri-layer coating consisting of $\mathrm{SiO}_{2}$-rich mullite, $\mathrm{Y}_{2} \mathrm{Si}_{2} \mathrm{O}_{7}$, and $70 \mathrm{wt} \% \mathrm{Y}_{2} \mathrm{Si}_{2} \mathrm{O}_{7}+30 \mathrm{wt} \% \mathrm{Y}_{2} \mathrm{SiO}_{5}$ has been fabricated on $\mathrm{C} / \mathrm{SiC}$ composite substrate through dip-coating route, and provides excellent oxidation protection for $\mathrm{C} / \mathrm{SiC}$ composite at 1400 and $1500{ }^{\circ} \mathrm{C}$ due to desirable thermal stability and further densification during high temperature oxidation. The carbothermal reaction between free carbon in substrate and rich $\mathrm{SiO}_{2}$ in mullite at $1600{ }^{\circ} \mathrm{C}$ leads to severe frothing and desquamation of coating, degrading oxidation resistance.

After 12 times of thermal shock from $1400{ }^{\circ} \mathrm{C}$ to room temperature in air, the flexural strength of coated composites is increased by $11.2 \%$ due to the preferable physical and chemical compatibility among $\mathrm{C} / \mathrm{SiC}$ substrate, mullite, and yttrium silicate as well as the further densification of coating.

\section{Acknowledgements}

The authors are grateful to the financial supports from the Aid Program for Science and Technology Innovative Research Team in Higher Educational Institutions of Hunan Province, and the Science Innovation Foundation of Shanghai Academy of Spaceflight Technology (No. SAST2015043).

\section{References}

[1] Kumar P, Srivastava VK. Tribological behaviour of C/C-SiC composites-A review. J Adv Ceram 2016, 5: $1-12$.

[2] Naslain R. Design, preparation and properties of non-oxide CMCs for application in engines and nuclear reactors: An overview. Compos Sci Technol 2004, 64: 155-170.

[3] Ma Q-S, Liu H-T, Pan Y, et al. Research progress on the application of $\mathrm{C} / \mathrm{SiC}$ composites in scramjet. $J$ Inorg Mater 2013, 28: 247-255.

[4] Li W, Chen ZH. Pore geometry of $3 \mathrm{D}-\mathrm{C}_{\mathrm{f}} / \mathrm{SiC}$ composites by mercury intrusion porosimetry. Ceram Int 2009, 35: 747-753.

[5] Qian Y, Zhang W, Ge M, et al. Frictional response of a novel $\mathrm{C} / \mathrm{C}-\mathrm{ZrB}_{2}-\mathrm{ZrC}-\mathrm{SiC}$ composite under simulated braking. J Adv Ceram 2013, 2: 157-161.

[6] Kousaalya AB, Kumar R, Packirisamy S. Characterization of free carbon in the as-thermolyzed $\mathrm{Si}-\mathrm{B}-\mathrm{C}-\mathrm{N}$ ceramic from a polyorganoborosilazane precursor. $J$ Adv Ceram 2013, 2: 325-332.

[7] Lodhe M, Babu N, Selvam A, et al. Synthesis and characterization of high ceramic yield polycarbosilane precursor for SiC. J Adv Ceram 2015, 4: 307-311.

[8] Xiang Y, Li W, Wang S, et al. Oxidation behavior of oxidation protective coatings for $\mathrm{PIP}-\mathrm{C} / \mathrm{SiC}$ composites at $1500{ }^{\circ} \mathrm{C}$. Ceram Int 2012, 38: 9-13.

[9] Xiang Y, Li W, Wang S, et al. Ablative property of $\mathrm{ZrC}-\mathrm{SiC}$ multilayer coating for $\mathrm{PIP}-\mathrm{C} / \mathrm{SiC}$ composites under oxy-acetylene torch. Ceram Int 2012, 38: 2893-2897.

[10] Huang J-F, Li H-J, Zeng X-R, et al. Yttrium silicate oxidation protective coating for $\mathrm{SiC}$ coated carbon/carbon composites. Ceram Int 2006, 32: 417-421.

[11] Argirusis C, Damjanović T, Borchardt G. Yttrium silicate coating system for oxidation protection of $\mathrm{C} / \mathrm{C}-\mathrm{Si}-\mathrm{SiC}$ composites: Electrophoretic deposition and oxygen self-diffusion measurements. J Eur Ceram Soc 2007, 27: 1303-1306.

[12] Aparicio M, Durán A. Preparation and characterization of $50 \mathrm{SiO}_{2}-50 \mathrm{Y}_{2} \mathrm{O}_{3}$ sol-gel coatings on glass and $\mathrm{SiC}(\mathrm{C} / \mathrm{SiC})$ composites. Ceram Int 2005, 31: 631-634.

[13] Zheng X, Du Y, Xiao J, et al. Celsian/yttrium silicate protective coating prepared by microwave sintering for C/SiC composites against oxidation. Mat Sci Eng A 2009, 505: 187-190.

[14] Bernardo E, Parcianello G, Colombo P. Novel synthesis and applications of yttrium silicates from a silicone resin containing oxide nano-particle fillers. Ceram Int 2012, 38: 5469-5474.

[15] Liu J, Zhang L, Hu F, et al. Polymer-derived yttrium silicate coatings on 2D C/SiC composites. $J$ Eur Ceram Soc 2013, 33: 433-439.

[16] Torrey JD, Bordia RK. Processing of polymer-derived ceramic composites coatings on steel. J Am Ceram Soc 2008, 91: 41-45.

[17] Liu J, Zhang L, Liu QM, et al. Polymer-derived SiOC-barium-strontium aluminosilicate coatings as an environmental barrier for $\mathrm{C} / \mathrm{SiC}$ composites. $J$ Am Ceram Soc 2010, 93: 4148-4152.

[18] Ma Q, Cai L. Fabrication of $\mathrm{Y}_{2} \mathrm{Si}_{2} \mathrm{O}_{7}$ coating and its oxidation protection for $\mathrm{C} / \mathrm{SiC}$ composites. Transactions of Nonferrous Metals Society of China 2017, 27: 390-396.

[19] Aparicio M, Durán A. Yttrium silicate coatings for oxidation protection of carbon-silicon carbide composites. $J$ Am Ceram Soc 2000, 83: 1351-1355.

[20] Zeng K, Ma Q, Cai L. Fabrication of mullite coating and 
its oxidation protection for carbon fiber reinforced $\mathrm{SiC}$ composites. Key Eng Mater 2016, 697: 476-480.

[21] Ma Q, Cai L. Preparation and anti-oxidation mechanism of mullite/yttrium silicate coatings on $\mathrm{C} / \mathrm{SiC}$ composites. $J$ Wuhan Univ Technol-Mat Sci Edit 2016, 31: 1284-1288.

[22] Huang J-F, Li H-J, Zeng X-R, et al. Oxidation resistant yttrium silicates coating for carbon/carbon composites prepared by a novel in-situ formation method. Ceram Int 2007, 33: 887-890.

[23] Lee NK, Fox DS, Bansal NP. Rare earth silicate environmental barrier coatings for $\mathrm{SiC} / \mathrm{SiC}$ composites and $\mathrm{Si}_{3} \mathrm{~N}_{4}$ ceramics. $J$ Eur Ceram Soc 2005, 25: 1705-1715.

[24] Sun Z, Li M, Zhou Y. Thermal properties of single-phase
$\mathrm{Y}_{2} \mathrm{SiO}_{5}$. J Eur Ceram Soc 2009, 29: 551-557.

[25] Huang JF, Li HJ, Zeng XR, et al. A new SiC/yttrium silicate/glass multi-layer oxidation protective coating for carbon/carbon composites. Carbon 2004, 42: 2356-2359.

Open Access The articles published in this journal are distributed under the terms of the Creative Commons Attribution 4.0 International License (http://creativecommons. org/licenses/by/4.0/), which permits unrestricted use, distribution, and reproduction in any medium, provided you give appropriate credit to the original author(s) and the source, provide a link to the Creative Commons license, and indicate if changes were made. 